\title{
The Pecking Order Theory and Start-up Financing of Small and Medium Enterprises: Insight into Available Literature in the Libyan Context
}

https://doi.org/10.21272/fmir.2(4).5-12.2018

Nassr Saleh Mohamad Ahmad

Professor, Accounting Faculty, University of Gharyan, Gharyan- Libya, General Manager of Human Resources Development Institute, Libyan Academy, Tripoli-Libya, Libya

\section{Mr. Ramadan Ahmed A Atniesha}

$\mathrm{PhD}$ Student, Faculty of Economic Sciences, University of Warsaw, Warsaw, Poland

\begin{abstract}
Purpose: The Pecking Order Theory states that internal financing is preferred when available; and, if external financing is required, debt is preferred over equity. Thus, this paper aims to test the application of The Pecking Order Theory as an exploitation of start-up financing of Small and Medium Enterprises in Libya. Design/Methodology/Approach: Desk research was used. A comprehensive literature search of published academic, peer reviewed professional literature using a variety of databases including journal articles, conference papers and thesis, both published and unpublished, was conducted. The main sources were the Internet.
\end{abstract}

Findings: By reviewing the available literature on access to finance by Small and Medium Enterprises in Libya, the Pecking Order Theory was supported.

Research limitations: This study is limited to start-up stage. Moreover, the main limitation of the literature review, as a study methodology, is that it relies on information which has already been researched. Thus, an empirical study is needed to provide more support to findings of this study.

Originality/Value: This is the first review of this area and thus should help intending and existing scholars. It could help policy makers to undertake some serious public policy serving the Small and Medium Enterprises access to finance.

Keywords: Small and Medium Enterprises; Pecking Order Theory; Start-Up Financing; Literature Review; Libya.

JEL Classification: G00, G14, G19.

(C) The Authors, 2018. This article is published with open access at Sumy State University.

Cite as: N. S. M. Ahmad, Mr. R. Ah. A. Atniesha. (2018). The Pecking Order Theory and Start-up Financing of Small and Medium Enterprises: Insight into Available Literature in the Libyan Context, Financial Markets, Institutions and Risks, 2(4), 5-12. https://doi.org/10.21272/fmir.2(4).5-12.2018.

\section{Introduction}

The firm life cycle is divided into four different stages. Each stage has its own prescribed characteristics. The different stages of the firm lifecycle are Birth or Startup stage, Growth stage, Maturity Stage and finally the Decline or Revival stage. The startup stage is considered to be the starting point where the entrepreneur tries to convert an idea into a business opportunity. In the startup stage founder and the key personnel are the main employees of the firm followed by small funding requirements.

Access to finance for startup firms has always been an issue of debate within the circle of Economists and Researchers. Issues related to the capital structure decision have attracted lot of attention, because of the reason that these issues are primarily dominant in small size and young firms. Capital structure has been defined as the mixture of debt and equity used to finance the business activities of a firm (Myers, 1984). The ability to gain adequate access to financial capital enables SMEs to establish and subsequently operate effectively. The capital structure decisions of SMEs therefore have important implications for their performance, their ability to succeed, their risk of failure and their potential for future development. 
Several major financial theories have been developed to explain the capital structures that firms adopt (Johnsen and McMahon, 2005). Pecking Order Theory (POT) is more suitable to identify the SME capital structure compared to other theories even though it is developed for large corporations (Mlohaolas et al., 1998, Osei-Assibey et al. 2011).

However, there is a lack of such studies in Libyan context, particularly in SMEs. Therefore, this study attempts to fill this gap in the finance literature addressing the research question, "To what extent does the POT appear to explain financial structure of SMEs in Libya?". Thus, the objectives of this study are two-fold: first, to investigate the financing preference of SMEs in Libya at start-up stage; second, to examine whether the POT can explain such financing preferences of SMEs in Libya at start-up stage. The study is organised as follows; Section two discusses the research methodology. Section three is devoted to a review of the relevance of POT for start-up SMEs. Section four dials with literature on SMEs start-up finance in Libya and application of POT. The last section concludes the paper.

\section{Research Methodology}

The research is based on the structured review of the literature. The first part of literature review includes the selection of most relevant articles on SMEs access to finance at start-up stage in Libya. A comprehensive literature search of published academic, peer reviewed professional literature using a variety of databases including journal articles, conference papers and thesis, both published and unpublished, was conducted. The main sources were the Internet. Once the articles are selected it is followed by the next step, which is the analysis of the selected articles. Based on the definitions of POT, the results of such studies will be analysed to find out various components that are available to answer the research questions of the paper. Furthermore, the results gathered from the analysis will be merged to give a meaningful interpretation and help in more structured literature review.

However, the main limitation of the literature review, as a study methodology, is that it relies on information which has already been researched (secondary information), and if there is none, then specific questions on the new study might not be adequately answered. Secondly, owing to different objectives and methodologies (and study designs) of previous studies, the data might not be in the right format or specific enough to answer the current study. Because of these limitations, a literature review is always conducted in preparation for primary and more detailed research (NCR, 2011). Thus, this research aims to provide a theoretical framework for the research followed by other researchers in future.

\section{The Relevance of POT for Start-up SMEs}

Financing decision at start-up stage of SMEs, selecting one or more sources of finance mainly depends on available financial sources in the financial system, preferences of owners and accessibility to finance. This decision is one of a vital decision for any firm regardless of the size, industry, etc. This is because business continuity has a direct relationship with firm finance and its effect on ability of taking competitive advantage (Heng and Azrabijani, 2012). As a result, financing decisions are imperative for SMEs similar to large enterprises as SMEs are functioning as backbone of any country specially a developing country like Libya. SMEs can use different types and sources of financing methods especially informal sources, which differ from traditional or formal sources of finance, namely equity and debt (Osei-Assibey, Bokpin \& Twerefou, 2012).

Johnsen and McMahon (2005) briefed five capable theories which is more relevant in SME financing, which named as Static Trade-off Theory, Agency Theory, Growth Cycle Theory, Alternative Resources (Bootstrapping) Explanations and Pecking Order Theory (POT). POT to date remains essential part of corporate finance. It is considered as one of the most influential theories (Mlohaolas et al., 1998, Osei-Assibey et al. 2011). The Pecking Order Model developed by Myers (1984). According to this model firms prefer internal funding over external funding. In case firms require external funding, they would prefer debt over equity. Traditional methods represent a logical sequence for start-up companies to start raising money, and most start-up companies enter the entrepreneurial world in this way. If the start-up project founders do not have their own financial resources (prefer internal funding) and cannot independently raise the start-up without external investments they usually turn to the traditional financing sources such as: $3 \mathrm{~F}$ (i.e. Friends, Family and Fools), business angels, bank loans and venture capital investments. Equity is generated as last resort (Chittenden et al., 1996; Abouzeedan, 2003; Beck and Demurguc-Kunt, 2006; He and Baker, 2007; Wu et al, 2008; Abdulsaleh and Worthington, 2013). 
The POT sought mainly to explain the observed financing practices of large publicly traded corporations. However, it was soon recognised that the theory may also relevance of SMES and apply to the financing practices of non-publicly traded SMEs that might not have the additional financing alternative of issuing external equity finance. Scherr et al. (1990, p. 10) consider the POT to be an appropriate description of SMEs' financing practices, because the 'Pecking order hypothesis is in keeping with the prior findings that debt is by far the 4 largest sources of external finance for small business'. In addition, Holmes and Kent (1991, p. 145) suggest that in SMEs 'managers tend to be the business owners and they do not normally want to dilute their ownership claim'. Thus, the issue of external equity finance, and the consequential dilution of ownership interest, may be further down the pecking order. The theory's application to SMEs implies that external equity finance issues may be inappropriate. In relation to the owner-manager's control over operations and assets, if the POT holds, then internal equity finance will be preferred, because this form of finance does not surrender control. When external financing is required, obtaining debt rather than equity finance is favoured, because this places fewer restrictions on the owner-manager.

A growing number of researchers have sought to establish whether the pecking-order theory can assist in explaining the capital structures adopted by SMEs (Jordan et al., 1998; Berggren et al, 2000; Zoppa and McMahon, 2002; Cassar and Holmes, 2004; Bundala, 2012; Meryen, 2014; Menike, 2015; Kuruppu and Azeez, 2016; Sarlija and Harc, 2016). However, little is known about the financial structure of startup SMEs in Libya (see for example Masoud, 2014). This study attempts to contribute to the existing literature focusing the debate on capital structure and financing behavior of SMEs from a developing country perspective and examines the capital structure and financing patterns that represents by Libyan SMEs based on POT.

\section{SMEs Start-up Finance in Libya and Application of POT}

3.1 Definition of SMEs in Libya. Understanding the SMEs and its contribution to the economy is not complete without identifying the still unresolved question of what really constitutes SMEs. There is no universally agreed definition of SMEs. Generally, there are two common approach to defining the SMEs (Raslimahmood, 2000). The first is a functional definition in which the small businesses are distinguished from the larger ones on the basis of suspected or proven characteristics. For example, Ang (1991), suggest that a business is classified as small if it possesses most of the following characteristics: (a) it has no publicly traded securities, (b) the owners have undiversified personal portfolios, (c) limited liability is absent or ineffective, (d) first generation owners are entrepreneurial and prone to risk taking, (e) the management team is not complete, (f) the business experiences the high cost of market and institutional imperfections, $(\mathrm{g})$ relationships with stakeholders are less formal, and (h) it has a high degree of flexibility in designing compensation schemes. The second approach to the definition of a small business employs some quantitative measures, such as number of employees, sales turnover, level of output or capital assets (Abdulsaleh and Worthington, 2013).

However, in Libya, the Ministry of Manpower, Training and Employment (MMTE) adopted the second approach in defining the SMEs in Libya. It establishes a national standard for SMEs, which stated that: "private productive or service businesses and instruments for economic and social development, accommodate the strengths of youth, and which includes professional administrative, and technical specifications which are suitable to operate efficiency" (Hajjaji, 2012, p.14). The MMTE classified SMEs in Libya as shown in the table (1).

Table 1. Libyan classification for productive, service, and commercial businesses

\begin{tabular}{|l|l|l|}
\hline \multicolumn{1}{|c|}{ Business } & \multicolumn{1}{c|}{ Size of employment } & \multicolumn{1}{c|}{ Size of fixed assets } \\
\hline Small & No more than 25 & Less than 2.5 Million Libyan Dinars \\
\hline Medium & $26-50$ & Less than 5 Million Libyan Dinars \\
\hline Large & More than 51 & More than 5 Million Libyan Dinars \\
\hline
\end{tabular}

Source: MMTE Report of 2004 (reported in Hajjaji, 2012).

Finally, it is worth to mention that there is a large number of SMEs in the Libyan economy, though the exact size of the sector is unknown. This is due to the fact that most SMEs in Libya have conducted their business outside the formal economy to avoid taxation and other fiscal and regulatory considerations (Porter and Yergin, 2006). Currently the SME sector is dominated by the production of food products, wood products, and metal for construction. Some SMEs also engage in the production of clothing, ceramics and bricks, grain milling and press and publication goods (Gunto and Alias, 2013). 
3.2. Importance of SMEs in Socio-Economic Development in Libya. In general, there is a growing recognition that SMEs can be a vital resource to combating some of the challenges facing the region by contributing to job growth and the economy, and bridging some of the regional economic development imbalances that have emerged within developed and developing countries (Gallagher and Stewart, 1984; Ganguly, 1985; Bums and Dewhurst, 1986; Dyson, 1990; Keasey and Watson, 1993; Berry and Levy, 1994; Binks et al., 1997; Cook and Nixson, 2000; Sanusi, 2003; OSCE, 2006; Ariyo, 2008; Kpelai, 2009; Ayozie and Latinwo, 2010; Emine, 2012; Muritala, et al., 2012; Kiraka, et al., 2013).

However, it is generally acknowledged that there is substantial evidence that SMEs face large growth constraints and have less access to formal sources of external finance, potentially explaining the lack of SMEs contribution to the country's economic growth (Coco, 2000; Hall et al., 2000; Cassar, 2004; Beck et al, 2006; Gilbert, 2008; Sarapaivanich and Kotey,2006; Beck and Kunt, 2007; Lin, 2007; Deakins et al., 2008; Zhao, 2008; Nichter, 2009; Shen et al., 2009; Klapper, 2010; Berger at et., 2011; Riding et al., 2010; Pandula, 2011; Anis and Mohamed, 2012; Terungwa, 2012; Kira, 2013).

Accordingly, SMEs are very important to Libyan economy because of the fact that the economy of Libya suffers from lack of economic diversification in its activities (Eltaweel, 2011; Abdwahab and Abdesamed, 2012; Zarook et al., $2013 \mathrm{a}, \mathrm{b}$ ). The government has proactively created the national programs for SMEs in 2008 to promote a vibrant SME sector. However, although $96 \%$ of the enterprises in Libya are SMEs, their contribution to the GDP of the country is only 4\% (Atniesha, 2009; Abdesamed and Abdwahab, 2012; Essmui et al., 2013). This is supported by UN's report of 2008. It stated that: "the contribution of SMEs to the Gross Domestic Product (GDP) is estimated to be less than 10 percent in most African counties" (UN, 2008, p. 6). The main aspects of this disadvantaged position is due to: (1) the Libyan economy is heavily dependent on the exports of oil for state revenue; more than $96 \%$ of exports are from the oil sector (Eltaweel, 2012, UN, 2008), and (2) the financial difficulties for these enterprises to have accessed for bank loan successfully (Zarook et al., $2013 \mathrm{a}, \mathrm{b}$ ).

3.3. Literature on SMEs Start-up Finance in Libya. By reviewing the available literature on SMEs start-up finance in Libya, one can say that in Libya, bank lending to SMEs Firms is relatively low ${ }^{1}$. Falah (2006) reported that only 4\% of Libyan SMEs borrow money from banks. Moreover, Eltaweel (2011) and Elmansori and Arthur (2013) found out that loans from banks represent only $11 \%$ and $8 \%$. Wahab and Furthermore, Abdesamed (2012) examined the issue of financing SMEs in the startup phase and when they were established as businesses. They found that $81.6 \%$ of startup firms used informal sources of finance and among these, $60.5 \%$ preferred personal savings, whereas only $17.1 \%$ preferred formal sources of finance. Moreover, $71.1 \%$ of the mature businesses were still using informal financing such as personal savings (25\%), family subsidies $(25 \%)$, trade credit $(15.8 \%)$ and their own profit $(5.3 \%)$, whereas $27.6 \%$ were relying on bank loans. Table (2) gives a description of this trend.

Table 2. Source of Finance of SMEs in Libya

\begin{tabular}{|l|c|c|c|}
\hline \multicolumn{1}{|c|}{ Source at the Startup stage } & Percentage & Source after the Startup stage & Percentage \\
\hline Personal Saving & 60.5 & Personal Saving & 25.0 \\
\hline Family Loan & 3.9 & Family Loan & 25.0 \\
\hline Friend Loan & 9.2 & Trade Credit & 15.8 \\
\hline Active Partner & 2.7 & Firm Profit & 5.3 \\
\hline Inactive Partner & 5.3 & & $\mathbf{2 7 . 6}$ \\
\hline Bank Loan & $\mathbf{1 7 . 1}$ & Bank Loan & 98.7 \\
\hline Total & 98.7 & Total & 1.3 \\
\hline Missing System & 1.3 & Missing System & 100 \\
\hline Overall Total & 100 & Overall Total & \\
\hline
\end{tabular}

Source: Abd Wahab and Abdesamed (2012, p. 1538-1539).

Abdulsaleh (2016, p. 142) stated that: "overall, the three most common sources of funds used by SMEs in the sample to finance business start-up were as follows: owner-managers' own savings, venture capital and bank finance. Just a above half of enterprises in the whole sample has used the own savings of their owner-managers as the primary source for start-up capital". Moreover, regarding to the source for post start-up, he stated that:"a cross the sample financing source generated internally (retained earnings and personal saving) were the most preferred source for ongoing finance... when it comes to external sources banks and trade credit from suppliers were found to be the most preferred other sources of finance (equity finance and government assistance) were

\footnotetext{
${ }^{1}$ In order to attain more in-depth understanding of the financing decisions of SMEs, see Ahmad and Atniesha (2014), who explored the effects of the internal, institutional and external factors on the accessing to bank loan by Libyan SMEs.
} 
found to be least" (pp. 144-145). However, Abdulsaleh and Worthington (2018) found out that bank loans in Libya are largely made on the strength of the relationship between the bank and the SME rather than the financial statement-, asset-, or credit scoring based approaches to bank lending found in more developed economies with stronger banking sectors.

Samawi et al. (2016, p. 1143) also confirmed such fact by saying that: "When asked about sources of finance, $75 \%$ of respondents said that they had started their businesses by using informal finance, which is consistent with the $73 \%$ of Libya SMEs that were found to rely on informal sources of funding in a study by Falah (2006). Most had used their personal and family savings at startup".

The above results of literature clearly consistent with the pecking order theory of capital structure and suggest that SMEs Start-up (even post start- up) finance in Libya tends to finance their expansion with debt over equity after exhausting their internal resources. This conclusion was supported by Masoud (2014) who stated that: "the empirical finding of this study contribute towards a better understanding of financing decisions of these firms can be explained by the determinants suggested by much of extant the empirical literature. Specifically, it is found that liquidity and profitability are negatively and significantly related to the leverage ratios, which is consistent with pecking order theory. This implies that firms prefer to finance investment with internally returned funds before issuing debt" (p. 79).

\section{Conclusion and Future Recommendations}

This study attempts to contribute to the existing literature focusing the debate on capital structure and financing behavior of SMEs from a developing country perspective and examines the capital structure and financing patterns that represents by Libyan SMEs based on Pecking Order Theory. Based on the literature review, it can be more or less concluded that financing businesses from personal savings, family and friends have been considered as very significant source for providing seed capital for most start-ups and expansion, as it remains the popular choice for SMEs in Libya. Moreover, when it comes to external sources banks and trade credit from suppliers were found to be the most preferred and equity finance was found to be least.

Although this study does not provide empirical evidences of SMEs but at least this study will contribute in addition of literature review and knowledge regarding SMEs in Libya. However, as the main limitation of the literature review, as a study methodology, is that it relies on information which has already been researched (secondary information), an empirical study is recommended to provide more support to findings of this study.

\section{References}

1. Abd Wahab, K. and Abdesamed, K. (2012). Small and Medium Enterprises (SMEs) Financing Practice and Accessing Bank Loan Issues -The Case of Libya, World Academy of Science, Engineering and Technology, 72(1), 1535-1540.

2. Abdesamed, K. and Abd Wahab, K. (2012). Do experience, Education and Business plan influence SMEs start-up Bank loan? The Case of Libya, Australian Journal of Basic and Applied Sciences, 6(12), 234239.

3. Abouzeedan, A. (2003). Financing Swedish Small and Medium-Sized Enterprises (SMEs): Methods, Problems and Impact, Paper presented at the 43rd European Congress of the Regional Science Association, Jyväskylä, Finland.

1. Abdulsaleh, A. and Worthington, A. (2013). Small and Medium-Sized Enterprises Financing: A Review of Literature, International Journal of Business and Management, 8(14), 36-54.

2. Abdulsaleh, A. (2016). Bank Financing for Small and Medium- Size Enterprises (SMEs) in Libya, PhD Thesis, Griffith Business School, Griffith University, Australia.

3. Abdulsaleh, A. and Worthington, A. (2018). Determines of SME Access to Bank Finance, International Journal of Management and Applied Science, 4(3), 46-51.

4. Ahmad, N. and Atniesha, R. (2014). Literature Review on Factors Influencing Accessing Bank Loan Issues of Small and Medium Enterprises (SMEs) in Libya, The Fourth Annual Conference of Economic Forum of Entrepreneurship and International Business, Paris, France, ECO-ENA: Economics \& ECOEngineering Associate, Inc.

5. Ang, J. (1991). Small Business Uniqueness and the Theory of Financial, Management, Journal of Small Business Finance, 1(1), 1-13

6. Anis, Omri and Frikha Mohamed. (2012). How entrepreneurs identify opportunities and access to external financing in Tunisian's micro-enterprises? African Journal of Business Management, 6, 4635-4647. 
7. Ariyo, D. (2008). Small firms are the backbone of the Nigerian Economy”, Africa Economic Analysis, Academy of Management Journal, 1(1), 109-124.

8. Atniesha, R. (2009). The Role of Bank Loans on the Development of Small Business in Libya, MSc Desertion, Libyan Academy, Tripoli, Libya.

9. Ayozie, D. and Latinwo, H. (2010). Entrepreneurial Developments and Small Scale Industry Contribution to Nigerian National Development: A Marketing Interface. Information Management and Business Review, 1 (2), 51-68.

10. Beck, A. and Demirguc-Kunt. (2007). Small and Medium Enterprises across the Globe: A New Database, Small Business Economics 29, 415-434; Klapper, Leaven and Rajan. Entry regulation as a barrier to entrepreneurship, Rauch. Modeling the informal sector formally.

11. Beck., T., Demirguç-Kunt., A., Luc Laeven and Vojislav Maksimovic. (2006). The Determinants of Financing Obstacles, Journal of International Money and Finance, 25, 932-952.

12. Berger, Allen N. Adrian M. Cowan \& W. Scott Frame. (2011). The Surprising Use of Credit Scoring in Small Business Lending by Community Banks and the Attendant Effects on Credit Availability, Risk, and Profitability Journal of Finance Service Research, 39 (1), 1-17.

13. Berggren, B., Olofsson, C., and Silver, L. (2000). Control Aversion and the Search for External Financing in Swedish SMEs", Small Business Economics, 15(3), 233-242. http://dx.doi.org/10.1023/A:1008153428618

14. Berry, A. And Levy, B. (1994). Indonesia. Small and Medium Sized Exports and Their support Systems, policy Research Working paper No. 1402, Policy research Department, The World Bank, Washington DC.

15. Binks, M. and Ennew, C. (1997). Small Business and Their Banks in the Year 2000; Cited in Harrison, R. T and Mason C. M. (1996), Development in the Promotion of Informal Venture Capital in the UK, International Journal of Entrepreneurial Behavior and Research, 2 (2), 6-33.

16. Bums, P. and Dewhurst, J. (1986). Small Businesses in Europe, Macmillan Press, London.

17. Cassar, G., (2004). The Financing of Business Start-ups. Journal of Business Venturing, 19(1), 261-283.

18. Bundala, N. (2012). Do Tanzanian Companies Practice Pecking Order Theory, Agency Cost Theory or Trade-Off Theory? An Empirical Study in Tanzanian Listed Companies, International Journal of Economics and Financial Issues, 2(4), 401-422.

19. Chittenden, F., Hall, G. and Hutchinson, P. (1996). Small Firm Growth, Access to Capital Markets and Financial Structure: Review of Issues and an Empirical Investigation, Small Business Economics, Vol. $8(1), 59-67$.

20. Coco, G. (2000). On the use of collateral. Journal of Economic Surveys, 14(2), 191-214.

21. Cook, P. and Nixson, F. (2000), Finance and Small and Medium Sized Enterprise Development; Finance and Development Research Program; Working Paper No. 14, Institute for Development Policy and Management, University of Manchester.

22. Deakins, D. North, D., Rob Baldock and Geoff Whittam. (2008). SMEs Access to Finance: Is Still a Debt Finance Gap? Institute for Small Business and Entrepreneurship, 3 (1), 11-19.

23. Dyson, K. (1990). Small and Medium Sized Enterprises, Spicers European Policy Reports, Rutledge, London.

24. Elmansori, E. and Arhur, L. (2013). Obstacles to Innovation faced by Small and Medium Enterprises (SMEs) in Libya, World Association for Sustainable Development (WASD) outlook, University of Sussex, Sussex, UK.

25. Eltaweel, M. (2011). Financing of Small Business in the Libyan Economic Environment, Unpublished $\mathrm{PhD}$ thesis, University of Gloucestershire, UK.

26. Emine, D. (2012). Financial Challenges That Impede Increasing the Productivity of SMEs in Arab Region, Journal of Contemporary Management Submitted on 12/July/2012.

27. Essmui, H., Berma, M., Shahadan, F. and Ramlee, S. (2013). Technical Efficiency of Manufacturing Enterprises in Libya: A Stochastic Frontier Analysis, International Journal of Management and Information Technology, 5(2), 528-535.

28. European Neighborhood and Partnership Instrument (ENPI). (2013). Libya Strategy Paper and National Indicative Programme, 2011 - 2013.

29. Falah. K. Ali. (2006). An Analysis Study to the Problems of Financing Small Projects with Reference to Experience of Libyan Development Bank in Darna City. Munich .J.,2006. Available http://mpra.ub.

30. Gallagher, C. and Stewart, H. (1984). Jobs and Business Life Cycle in the UK. Research Report 2, Department of Industrial Management, University of Newcastle Upon Tyne.

31. Ganguly, P. (1985). UK Small business Statistics and International Comparisons, Harper \& Row, London. 
32. Cassar, G. and S. Holmes (2003). Capital Structure and Financing of SMEs: Australian Evidence, Accounting and Finance, 43, 123-147.

33. Gunto, M. and Alias, M. (2013). SMEs Development in Malaysia: Lessons for Libya, PROSIDING PERKEM VIII, JILID, 3, 1521 - 1530.

34. Hajjaji, I (2012). An Exploration of influences on the Growth of Small Firms in Libya, Unpublished PhD thesis, University of Gloucestershire, UK.

35. Hall, G., Hutchinson, P., and Michealas, N. (2000). Industry Effect on the Determinants of Unquoted SMEs Capital Structure. International Journal of the Economic of Business, 7(3), 297-312.

36. He, W., and Baker, H (2007). Small Business Financing: Survey Evidence in West Texas, The Journal of Entrepreneurial Finance and Business Ventures, 12(1), 27-54.

37. Keasey, K. and Watson, R. (1993). Small Firms Management: Ownership, Finance and Performance, Blackwell, Oxford.

38. Kira, A. (2013). The Evaluation of the Factors Influence the Access to Debt Financing by Tanzanian SMEs, European Journal of Business and Management, 5(7), 1-24.

39. Kuruppu, G. and Azeez, A. (2016). Financing Preferences of Small and Medium Enterprise Owners of Sri Lanka: Does Pecking Order Theory Hold? Journal of Business \& Economic Policy, 3 (2), 79-92.

40. Jordan, J., Lowe, J., \& Taylor, P. (1998). Strategy and Financial Policy in UK Small Firms. Journal of Business Finance and Accounting, 25(1-2), pp.1-27. http://dx.doi.org/10.1111/1468-5957.00176.

41. Johnsen, P. and McMahon R. (2005). Cross-industry Differences in SME financing Behaviour: An Australian Perspective, Journal of Small Business and Enterprise Developemnt, 12(2), 160-177.

42. Kiraka, R., Kobia, M. and Katwalo, A. (2013), Micro, Small and Medium Enterprise Growth and Innovation in Kenya: A Case Study on the Women Enterprise Fund, ICBE-RF Research Report No. 47/13, Investment Climate and Business Environment Research Fund (ICBE-RF), Dakar.

43. Klapper, L., Laeven, L., and Rajan, R. (2010). Entry Regulation as a Barrier to Entrepreneurship, Journal of Financial Economics, 82(3), 591-623.

44. Kpelai, T. (2009). Entrepreneurship development in Nigeria, Makurdi: Aboki Publishers.

45. Lin, Y. F. (2007). Developing Small and Medium Bank to Improve Financial Structure, Working paper, China Center for Economic Research, Peking University (in Chinese) cited in Emine, D. (2012), Financial Challenges That Impede Increasing the Productivity of SMEs in Arab Region, Journal of Contemporary Management Submitted on 12/July/2012.

46. Masoud, N. (2014). The Determinants of Capital Structure Choice: Evidence from Libyan Firms", Research Journal of Finance and Accounting, 5 (1), 67-83.

47. Menike, L. (2015). Capital Structure and Financing of Small and Medium Sized Enterprises: Empirical Evidence from a Sri Lankan Survey, Journal of Small Business and Entrepreneurship Development, 3(1), 54-65.

48. Meryem, A. (2014). The Pecking Order Theory and SMEs Financing: Insight into the Mediterranean Area and a Study in the Moroccan context, IJEMS, 7 (2), 109-206.

49. Mlohaolas, N., Chittenden, F., and Poutziourie, P. (1998). A Model of Capital Structure Decision making in Small Firms, Small Business and Enterprise Development, 5, 246-260.

50. Muritala, T. Awolaja, A. and Bako, Yusuf. A. (2012). Impact of Small and Medium Enterprises on Economic Growth and Development. American Journal of Business and Management, 1(1), 18-22.

51. Musamali, M. and Tarus, D. (2013). Dose Firm Profile Influence Financial Access among Small and Medium Enterprises in Kenya? Asian Economic and Financial Review, 3 (6), 714-723.

52. Myers, S. (1984). The Capital Structure Puzzle, The Journal of Finance, 39(3), 575-592.

53. NCR (National Credit Regulator) (2011). Literature Review on Small and Medium Enterprises' Access to Credit and Support in South Africa, Pretoria, South Africa.

54. Nichter, Simeon and Lara Goldmark. (2009). Small Firm Growth in Developing Countries, Journal of World Development, 37(1), 1453-1464.

55. Organisation for Security and Cooperation in Europe (OSCE) (2006). Small and Medium Sized Enterprises: Development and Promotion, Best-Practice Guide for a Positive Business.

56. Osei-Assibey, E., Bokpin, G. A., and Twerefou, D. K. (2011). Microenterprise Financing Preference: Testing POH within the Context of Ghana's Rural Financial Market. Economic Studies, 39, 84-105.

57. Pandula, G. (2011). An Empirical Investigation of Small and Medium Enterprises' Access to Bank Finance: The Case of an Emerging Economy. Proceedings of ASBBS, Annual Conference, 18(1), 255273.

58. Porter, M. E., and Yergin, D. (2006). National Economic Strategy, an Assessment of the Competitiveness of Libya. The Monitor Group Report. 
59. Raslimahmood. (2000). An Empirical Investigation of the Lending Decisions on Small Business by Band Managers in Malaysia, Unpublished PhD thesis, University of Glasgow, UK.

60. Riding, Allan., Barbara J., Orser. Martine Spence and Brad Belanger. (2010). Financing New Venture Exporters, Journal Small Business Economics, DOI10.1007/s11187-009-9259-6.

61. Sanusi, J. O. (2003). Overview of Government's Efforts in the Development of SMEs and the Emergence of Small and Medium Industries Equity Investment Scheme (SMIEIS). A Paper Presented at the National Summit on SMIEIS Organised by the Bankers' Committee and Lagos Chambers of Commerce and Industry (LCCI), Lagos, 10th June. [Online].

62. Sarapaivanich, N., \& Kotey, B. (2006). The Effect of Financial Information Quality on Ability to Access External Finance and Performance of SMEs in Thailand, Journal of Enterprising Culture, 14(3), 219-239.

63. Sarlija, N. and Harc, M. (2005). Capital Structure Determinant of Small and Medium Enterprises in Croatia, Managing Global Transition, 14 (3), 251-266.

64. Shen, Yan., Shen, Minggao., Xu Zhong and Bai Ying. (2009). Bank Size and Small- and Medium- sized Enterprise (SME) Lending: Evidence from China, World Development, 37 (4), 800-811.

65. Samawi, A., Mdanat, M., Yosef, F. and Abutayeh, B. (2016). Formal versus Informal Financing of SMEs in the Libyan Context: The Case of Ghrian City, Proceedings of 33rd International Business Research Conference 4 - 5 January 2016, Flora Grand Hotel, Dubai, UAE, ISBN: 978-1-922069-94-8.

66. Terungwa, A (2012). Financing Options Available to Small and Medium Scale Enterprises (SMEs) in Nigeria: a Critique, International Trade \& Academic Research Conference (ITARC), 7 - 8th November, London.UK.

67. UN (United Nations). (2008). SMEs Actors for Sustainable Development in North Africa, Economie Commission for Africa, Office of North Africa.

68. Wu, J., Song, J., and Zeng, C. (2008). An Empirical Evidence of Small Business Financing in China", Management Research News, 31(1), 959-975.

69. Zarook, T., Rahman, M. and Khanam, R. (2013a). Management Skills and Access to Finance: Evidence from Libya's SMEs, International Journal of Business and Management, 4(7), 55-65.

70. Zarook, T., Rahman, M. and Khanam, R. (2013b). Does the Financial Performance Matter in Accessing to Finance for Libya's SMEs? International Journal of Business and Management, 5 (6), 11-19.

71. Zarook, T., Rahman, M. and Khanam, R. (2013c). The Impact of Demographic Factors on Accessing Finance in Libya's SMEs, International Journal of Business and Management, 8 (14), 55-65.

72. Zhao, J (2008). Research on the Financing of Small and Medium Enterprises, International Journal of Business and Management, 3 (11), 171-174.

73. Zoppa, A. and McMahon, R. (2002). Pecking Order Theory and the financial Structure of Manufacturing SMEs from Australia's Business Longitudinal Survey, Research Paper Series: 02-1, School of Commerce, The flinders University of South Australia. 